\title{
Decomposition of rice chaff using a cocultivation system of Thermobifida fusca and Ureibacillus thermosphaericus ${ }^{+}$
}

\author{
Sachiko Nakamura ${ }^{1}$ and Norio Kurosawa ${ }^{1, *}$ \\ 1 Department of Environmental Engineering for Symbiosis, Graduate School of Science and Engineering, \\ Soka University, 1-236 Tangi-machi, Hachioji, Tokyo 192-8577, Japan \\ * Correspondence: kurosawa@soka.ac.jp \\ + Presented at the 1st International Electronic Conference on Microbiology, 2-30 November 2020; Available \\ online: https://ecm2020.sciforum.net/
}

Published: 2 November 2020

\begin{abstract}
Lignocellulosic biomass comprises cellulose, hemicellulose, and lignin and is a potential source of fuels and chemicals. Although this complex biomass is persistent, it can be cooperatively decomposed by a microbial consortium in nature. In this study, a coculture of the moderately thermophilic bacteria Thermobifida fusca and Ureibacillus thermosphaericus was used for biodegradation of rice chaff. The bacterial strains were incubated in modified Brock's basal salt medium ( $\mathrm{pH}$ 8.0) supplemented with yeast extract and rice chaff at $50^{\circ} \mathrm{C}$ for 7 days. The concentration of reducing sugars and the enzymatic activities of laccase, lignin peroxidase, cellulase, and xylanase in the supernatant of the culture medium were measured every day. The concentrations of reducing sugars in solo cultures of T. fusca and $U$. thermosphaericus and a mixed culture of the two strains after 7 days of incubation were $0.047 \mathrm{mg} / \mathrm{mL}, 0.040 \mathrm{mg} / \mathrm{mL}$, and $0.195 \mathrm{mg} / \mathrm{mL}$, respectively, indicating that the decomposition of rice chaff was enhanced in the coculture. Based on the results, it is thought that the lignin surrounding the cellulose was decomposed by laccase and lignin peroxidase secreted from $U$. thermosphaericus, resulting in cellulose and hemicellulose in the rice chaff being easily decomposed by enzymes from T. fusca.
\end{abstract}

Keywords: Lignocellulose; cocultivation; moderately thermophilic bacteria; laccase; lignin peroxidase; cellulase; xylanase

\section{Introduction}

Lignocellulosic biomass constitutes the cell wall of plants, and this decomposition product has been attracting attention as a raw material for bioethanol and biodegradable plastics. However, this biomass is not easily decomposed, as it has a strong structure in which polymers such as cellulose, hemicellulose, and lignin are linked by hydrogen bonds or covalent bonds. For this reason, decomposition treatment with an acid has been attempted, but this method has the problem that aromatic compounds are generated and mix with the decomposition products. On the other hand, enzymatic decomposition is less efficient than chemical decomposition. In nature, lignocellulose is degraded through a complex multistep process by the cooperation of various microorganisms that produce synergistic cellulolytic enzymes, hemicellulytic enzymes and lignin-degrading enzymes [1]. In addition, coculture of microorganisms may induce higher enzyme production than single cultures due to synergistic effects [2,3]. It is considered very difficult to maintain a wide variety of microbial communities in a reactor and perform specific biomass decomposition, but it may be possible to construct a coculture system for a few species of microorganisms. In fact, Shiotani et al. [4] reported that the decomposition of aquatic plants was promoted under the coculture of the cellulose/hemicellulose-degrading bacterium Thermobifida fusca and the lignin-degrading bacterium Ureibacillus thermosphaericus. These bacteria are moderately thermophilic and have similar optimal growth temperatures and $\mathrm{pH}$ values. In this study, a coculture of T. fusca and $U$. thermosphaericus was used for the biodegradation of rice chaff. 


\section{Materials and Methods}

Thermobifida fusca DSM43792 and Ureibacillus thermosphaericus DSM10633 were purchased from the Deutsche Sammlung von Mikroorganismen und Zellkulturen (DSMZ). The bacterial strains were incubated in modified Brock's basal salt medium [5] ( $\mathrm{pH} 8.0)$ supplemented with yeast extract $(0.5 \%)$ and rice chaff $(0.5 \%)$ at $50^{\circ} \mathrm{C}$ for 7 days. The concentration of reducing sugars was determined using the dinitrosalicylic acid method [6]. The enzymatic activities of laccase, lignin peroxidase, cellulase, and xylanase in the supernatant of the culture medium were measured every day according to standard methods [7-9]. The viable cells in each culture were counted as colony-forming units. To investigate the effect of the mixing ratio of the two strains on rice chaff decomposition, a culture experiment was conducted in which the mixing ratio of the strains was varied.

\section{Results and Discussion}

\subsection{Cell density}

The cell density of T. fusca gradually increased, reaching $2.3 \times 10^{6}$ cells $/ \mathrm{mL}$ on the 7 th day. On the other hand, the cell density of $U$. thermosphaericus showed a maximum value of $5.3 \times 10^{9}$ cells $/ \mathrm{mL}$ on the second day and then gradually decreased. The cell density of the coculture reached $4.6 \times 108$ $\mathrm{CFU} / \mathrm{mL}$ on the second day and was maintained at $>3.3 \times 10^{7} \mathrm{CFU} / \mathrm{mL}$ throughout the study period (Fig. 1a).

\subsection{Concentration of reducing sugar}

The concentrations of the reducing sugars in the single cultures of $T$. fusca and $U$. thermosphaericus and the mixed culture of the two strains showed maximum values of $0.111 \mathrm{mg} / \mathrm{mL}$, $0.040 \mathrm{mg} / \mathrm{mL}$, and $0.225 \mathrm{mg} / \mathrm{mL}$, respectively, indicating that the decomposition of rice chaff was enhanced in the coculture (Fig. 1b).

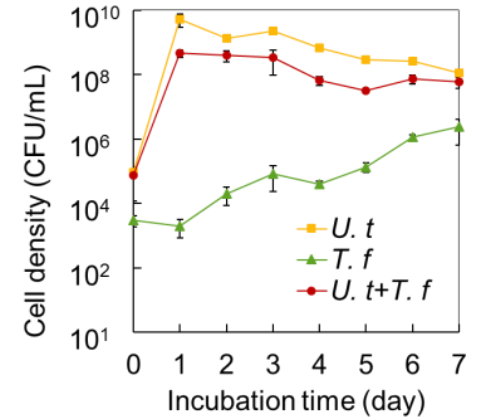

(a)

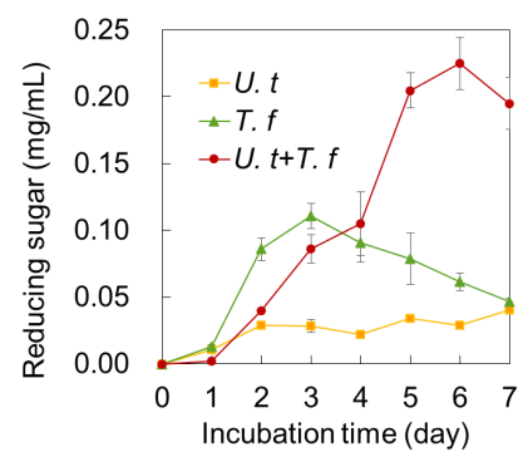

(b)

Figure 1. Cell densities (a) and reducing sugar production (b) in the cultures of T. fusca, U. thermosphaericus and both strains.

\subsection{Enzymatic activities}

The activities of lignin peroxidase, cellulase, and xylanase were higher in the coculture than in the single culture. The laccase activity was higher in the culture of $U$. thermosphaericus alone than in the coculture (Fig. 2). 


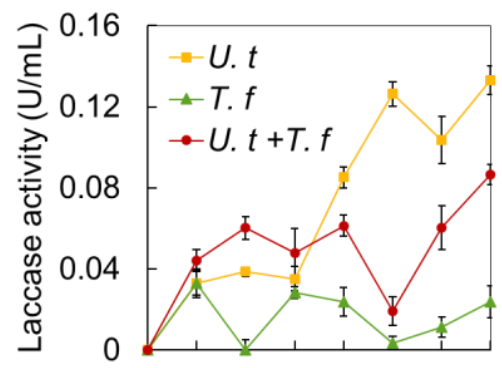

(a)

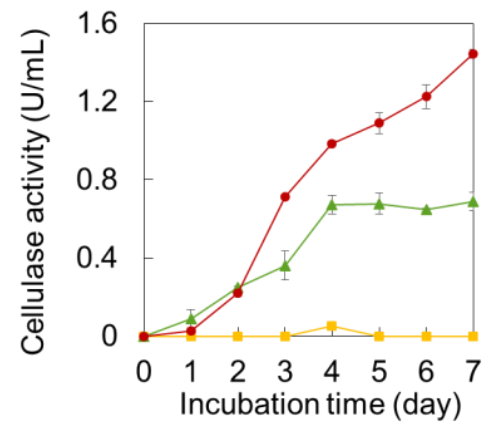

(c)

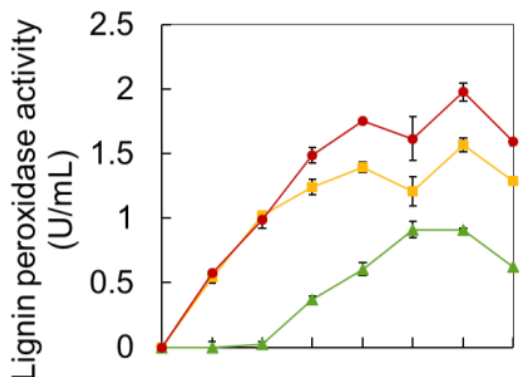

(b)

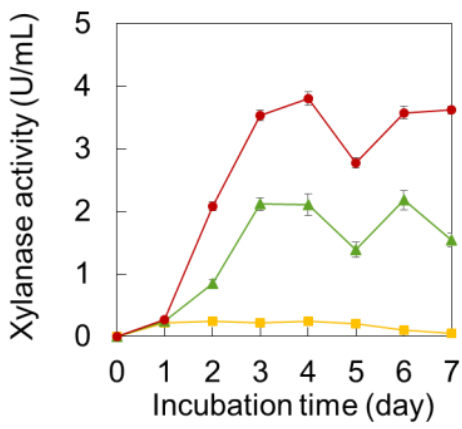

(d)

Figure 2. Laccase activity (a), lignin peroxidase activity (b), cellulase activity (c), and xylanase activity (d) in cultures of T. fusca, U. thermosphaericus and both strains.

\subsection{Influence of the mixture ratio of the coculture}

The enzymatic activities were higher in the coculture than in the single cultures except when the inoculation amount of $T$. fusca was very small. It was possible to start a coculture with a relatively wide range of inoculum mixture ratios.

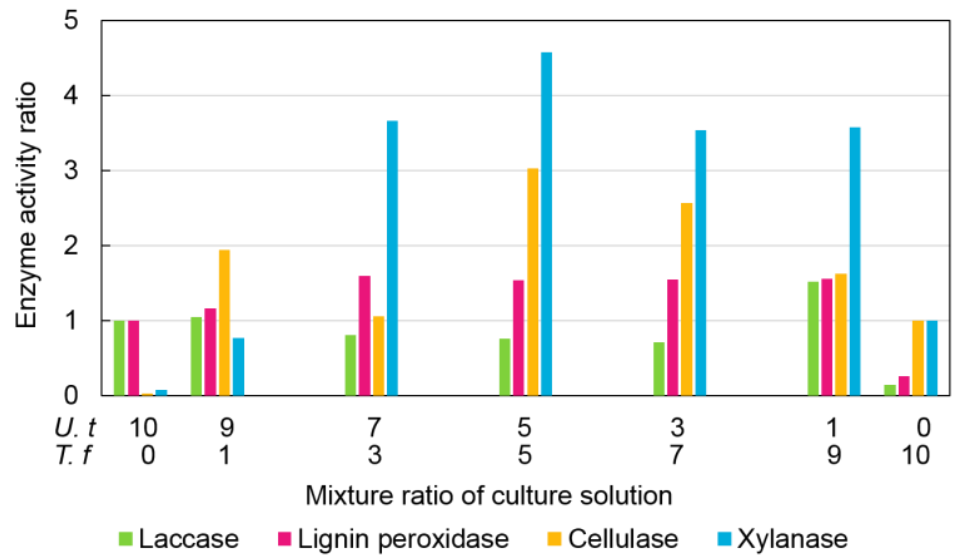

Figure 3. Influence of the mixture ratio of $T$. fusca and $U$. thermosphaericus inoculums on each enzyme activity after 7 days of incubation. Laccase and lignin peroxidase activities are expressed in ratios based on the $U$. thermosphaericus monoculture. The cellulase and xylanase activities are expressed in ratios based on the T. fusca monoculture.

\section{Conclusions}

A cocultivation system of $T$. fusca and $U$. thermosphaericus was applied for the decomposition of rice chaff, a model compound of lignocellulosic biomass. Both the concentration of reducing sugars and the enzymatic activities were higher in the coculture than in the single cultures. Based on the results, it is thought that the lignin surrounding the cellulose was decomposed by laccase and lignin peroxidase secreted from $U$. thermosphaericus, resulting in the cellulose and hemicellulose in the rice chaff being easily decomposed by the enzymes from $T$. fusca. 
Author Contributions: Conceptualization, N.K.; methodology, N.K.; validation, S.N. and N.K.; formal analysis, S.N.; investigation, S.N. and N.K.; resources, N.K.; data curation, N.K.; writing-original draft preparation, S.N.; writing - review and editing, N.K.; supervision, N.K.; All authors have read and agreed to the published version of the manuscript.

Conflicts of Interest: The authors declare no conflicts of interest.

\section{References}

1. Wongwilaiwalin, S., Laothanachareon, T., Mhuantong, W., Tangphatsornruang, S., Eurwilaichitr, L., Igarashi, Y., Champreda, V. Comparative metagenomic analysis of microcosm structures and lignocellulolytic enzyme systems of symbiotic biomass-degrading consortia. Appl. Microbiol. Biotechnol. 2013, 97, 8941-8954.

2. Belenguer, A., Duncan, S. H., Calder, A. G., Holtrop, G., Louis, P., Lobley, G.E., Flint, H.J. Two Routes of Metabolic Cross-Feeding between Bifidobacterium adolescentis and Butyrate-Producing Anaerobes from the Human Gut. Appl. Environ. Microbiol. 2006, 72, 3593-3599.

3. Geib, S.M., Filley, T.R., Hatcher, P.G., Hoover, K., Carlson, J.E., Jimenez-Gasco, M.M., Nakagawa-Izumi, A., Sleoghter, R.L., Tien, M. Lignin degradation in wood-feeding insects. Proc. Natl. Acad. Sci. USA. 2008, 105, 12932-12937.

4. Shioya, S. Optimization of bioprocess systems. Seibutsu-kogaku. 2010, 88, 2-10. (in Japanese)

5. Kurosawa, N., Itoh, Y.H., Iwai, T., Sugai, A., Uda, I., Kimura, N., Horiuchi, T., Itoh, T. Sulfurisphaera ohwakuensis gen. nov., sp. nov., a novel extremely thermophilic acidophile of the order Sulfolobales. Int. J. Syst. Bacteriol. 1998, 48, 451-456.

6. Miller, G.L. Use of dinitrosalicylic acid regent for determination of reducing sugar. Anal. Chem. 1959, 31, 426-428.

7. Wongwilaiwalin, S., Laothanachareon, T., Mhuantong, W., Tangphatsornruang, S., Eurwilaichitr, L., Igarashi, Y., Champreda, V. Comparative metagenomic analysis of microcosm structures and lignocellulolytic enzyme systems of symbiotic biomass-degrading consortia. Appl. Microbiol. Biotechnol. 2013, 97, 8941-8954.

8. Schlosser, D., Grey, R., Fritsche, W. Patterns of ligninolytic enzymes in Trametes versicolor. Distribution of extra- and intercellular enzyme activities during cultivation on glucose, wheat straw and beech wood. Appl. Microbiol. Biotech. 1997, 47, 412-418.

9. Saha B. C., Iten L. B, Cotta M. A., Wu Y. V. Dilute acid pretreatment, enzymatic saccharification and fermentation of wheat straw to ethanol. Process Biochem. 2005, 40, 3693-3700.

Publisher's Note: MDPI stays neutral with regard to jurisdictional claims in published maps and institutional affiliations.

(C) 2020 by the authors; licensee MDPI, Basel, Switzerland. This article is an open access article distributed under the terms and conditions of the Creative Commons Attribution (CC-BY) license (http://creativecommons.org/licenses/by/4.0/). 